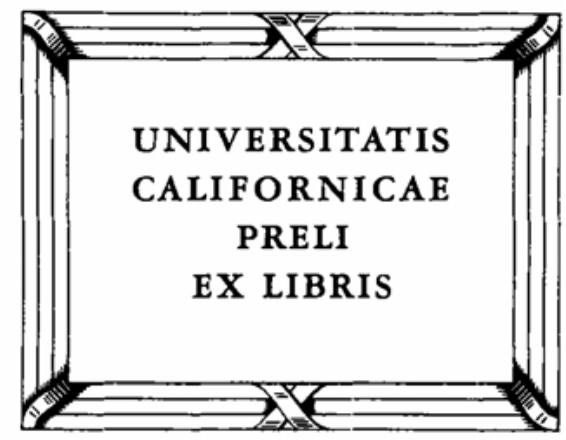


PREVIOUSLY PUBLISHED IN THIS SERIES

Educational Foundations of the Tesuits in Sixteenth-Century New Spain

By Jerome V. Jacobsen, S.J., Ph.D.

Pioneer Black Robes on the West Coast

By Peter Masten Dunne, S.J., Ph.D. 


\section{PIONEER JESUITS IN NORTHERN MEXICO}

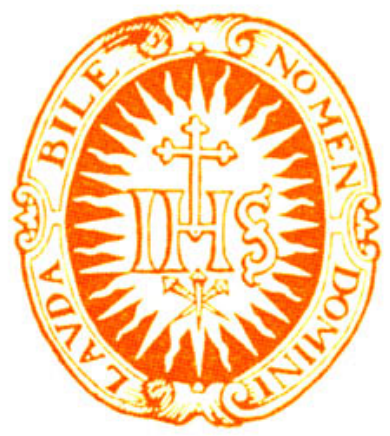




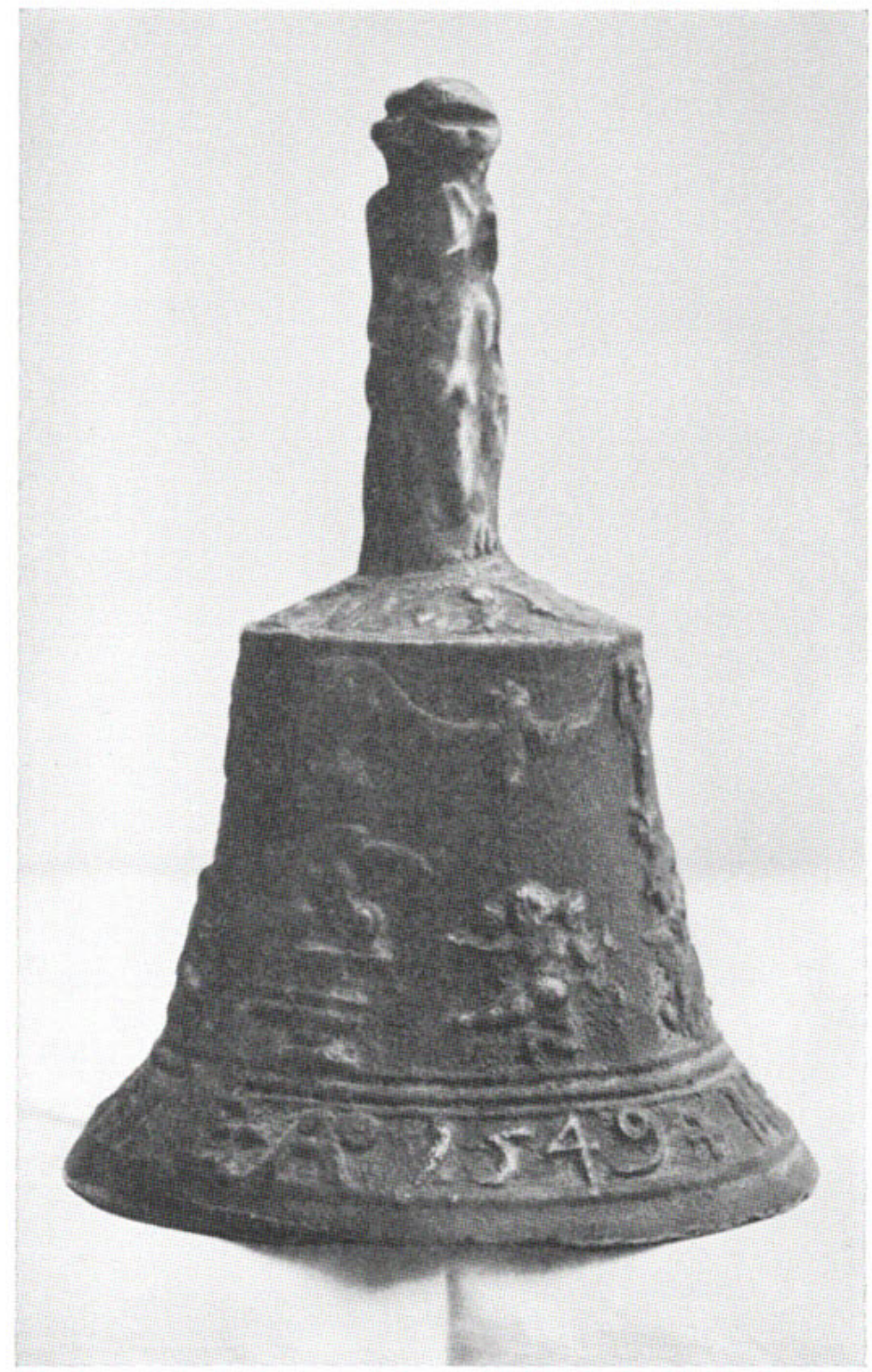

A RELIC OF EARLY DAYS AT PARRAS 


\section{Píneer Jesuíts in Northern Mexíco W}

By Peter Masten Dunne, S.J.

University of California Press Berkeley and Los Angeles · 1944 


\section{UNIVERSITY OF CALIFORNIA PRESS \\ BERKELEY AND LOS ANGELES \\ CALIFORNIA \\ $\prec$ \\ CAMBRIDGE UNIVERSITY PRESS \\ LONDON, ENGLAND}

COPYRIGHT, 1944, BY

THE REGENTS OF THE UNIVERSITY OF CALIFORNIA

PXINTED IN THE UNITED STATES OF AMERICA

BY THE UNIVERSITY OF CALIFORNIA PRESS 
TO

HERBERT EUGENE BOLTON

INSPIRER OF

THIS SERIES OF STUDIES

HISTORIAN AND ASSIDUOUS COLLECTOR OF

HISTORICAL DOCUMENTS 
